\title{
Immunoassay of gonadotrophin-releasing hormone in brain tissue of Booroola Merino ewes
}

\author{
J. S. Gale, P. Smith, P. Truman and K. P. McNatty \\ Department of Biochemistry, Victoria University of Wellington, Private Bag, Wellington, \\ New Zealand, and Wallaceville Animal Research Division, Ministry of Agriculture and Fisheries, \\ Private Bag, Upper Hutt, New Zealand
}

\begin{abstract}
Summary. The presence of a fecundity gene $(F)$ in Booroola Merino ewes increases the ovulation rate. To test how $\mathrm{F}$ gene expression affects the gonadotrophin-releasing hormone $(\mathrm{GnRH})$ concentration in hypothalamic or extrahypothalamic regions of the brain, GnRH was measured by radioimmunoassay in acetic acid extracts of various brain tissues from Booroola ewes which were homozygous $(F F)$, heterozygous $(F+)$ or non-carriers $(++)$ of the $F$ gene. The GnRH concentration in brain tissues from FF, $\mathrm{F}+$ and ++ animals which had been ovariectomized 5 months previously was also evaluated.

No significant $F$ gene-specific differences were noted in any of the brain areas tested, in intact or ovariectomized animals. However, in ovariectomized ewes, the concentrations of GnRH increased about 2-fold in the median eminence of the hypothalamus, remained unchanged in the medial basal hypothalamus and dropped to $<10 \%$ of the values in intact ++ animals in the preoptic area.

These studies suggest that the changed pituitary sensitivity and increased gonadotrophin release in Booroolas carrying the $\mathrm{F}$ gene(s) is not attributable to increased hypothalamic GnRH concentrations in these animals.
\end{abstract}

Keywords: GnRH; sheep; brain; Booroola; F-gene

\section{Introduction}

The Booroola Merino breed of sheep carries a major fecundity gene(s) (F) which influences the ovulation rate (Bindon, 1984). Ewes homozygous for the $F$ gene (i.e. FF animals) produce $\geqslant 5$ ovulations, compared with 3-4 in heterozygous $(F+)$ ewes and 1 or 2 in the non-F gene carriers (i.e. ++ animals) (Davis et al., 1982). Follicles in FF animals develop the ability to synthesize oestradiol and reach ovulatory maturity at a smaller diameter than in ++ animals. However, the number of granulosa cells per oestrogenic follicle is significantly less in the FF compared with that in follicles from $\mathrm{F}+$ ewes, which in turn, is less than that in ++ ewes so that the overall steroid output from both ovaries is similar in all 3 genotypes (McNatty et al., 1986).

Booroola Merinos with the F gene have been shown to have higher pituitary contents of immunoreactive follicle-stimulating hormone (FSH) than ++ ewes (Robertson et al., 1984; Bindon, 1984; Bindon et al., 1985; McNatty et al., 1987). Moreover, McNatty et al. (1987) have shown that the mean plasma concentrations of immunoreactive forms of FSH and luteinizing hormone (LH) are higher in FF ewes than in ++ ewes. The amplitude of the $\mathrm{LH}$ pulses is 2- to 3-fold higher in FF ewes compared to that in ++ ewes, with the $\mathrm{F}+$ ewes having an intermediate $\mathrm{LH}$ pulse amplitude; in all three genotypes the $\mathrm{LH}$ pulse frequencies are similar. In contrast, the $\mathrm{LH}$ released in response to exogenous gonadotrophin-releasing hormone $(\mathrm{GnRH})$ is significantly lower in FF ewes than ++ ewes, with the $\mathrm{F}+$ animals showing an intermediate response. These LH responses in vivo suggest 
that the pituitaries of $F$ gene carriers are being desensitized to high doses of exogenous GnRH stimulation.

To investigate the possibility that $F$ gene expression affects the GnRH concentrations in the hypothalamus, we have measured GnRH immunoactivity in acetic acid extracts of various hypothalamic and extrahypothalamic areas of the brains from intact and ovariectomized $\mathrm{FF}, \mathrm{F}+$ and ++ ewes.

\section{Materials and Methods}

Sheep. The animals in these studies were 6-8-year-old parous Booroola Merino ewes. The FF and F+ genotypes were the resultant progeny of,$++ F+$ or $F F$ ewes mated with progeny from $F F \times F F$ matings. All of the ewes from the above matings were assigned their genotypes after 4-5 annual ovulation rate recordings at laparoscopy (Davis $e t$ al., 1982). The ++ ewes were the offspring of a progeny-tested ++ Booroola Merino ram run with Merino ewes. Some of the ewes had been ovariectomized 5-6 months before death.

Brain dissection. The animals were decapitated and the heads chilled to $4^{\circ} \mathrm{C}$ within $10 \mathrm{~min}$ of death. Brains were removed and dissected within $2 \mathrm{~h}$ of death. Pieces of frontal lobe cerebral cortex $(\sim 1 \mathrm{~g})$, the pineal body $(\sim 95 \mathrm{mg})$ and median eminence (ME, $\sim 25 \mathrm{mg}$ ) were removed and frozen at $-70^{\circ} \mathrm{C}$. The medial basal hypothalamus (MBH) was defined as the area above the ME, bounded rostrally by the posterior edge of the optic chiasma and caudally by the mamillary bodies. The MBH was approximately $10 \mathrm{~mm}$ wide and $5 \mathrm{~mm}$ deep and weighed $250-300 \mathrm{mg}$. A block of anterior hypothalamic tissue was cut from the chilled brain, rostral to the anterior edge of the optic chiasma and $10 \mathrm{~mm}$ thick and frozen at $-70^{\circ} \mathrm{C}$. Frontal slices $\sim 1 \mathrm{~mm}$ width were cut from this frozen block using a single-edged razor blade. The preoptic area $(\sim 90 \mathrm{mg})$ and septal nuclei $(\sim 80 \mathrm{mg})$ were removed by the punch technique of Palkovits (1973) from the slice in which the anterior commissure appeared as a horizontal band of white matter on the caudal surface. The organum vasculosum of the lamina terminalis (OVLT) and parts of the supraoptic nuclei (SON) were removed from the ventral surface of the slice immediately anterior to this $(\sim 50 \mathrm{mg})$. The above dissected pieces were stored at $-70^{\circ} \mathrm{C}$ until extraction and assay.

GnRH extraction and radioimmunoassay. GnRH was extracted by homogenization of tissue samples in 9 volumes of $0 \cdot 2 \mathrm{M}$-acetic acid using an Ultra-Turrax shearing homogenizer (Janke \& Kunkel GmbH, Stauffen, W. Germany). Homogenates were incubated at $100^{\circ} \mathrm{C}$ for $5 \mathrm{~min}$, cooled on ice and centrifuged at $12000 \mathrm{~g}$ for $30 \mathrm{~min}$ at $4^{\circ} \mathrm{C}$. Aliquants of the clear supernatant were lyophilized and stored at $-20^{\circ} \mathrm{C}$ until radioimmunoassay (RIA).

Extracts were immunoassayed for GnRH using antiserum CRR11B73 (a gift from Dr Y. F. Chen and Dr V. D. Ramirez, University of Illinois, IL, U.S.A.), which requires the complete decapeptide sequence for binding. This antiserum has $<0.001 \%$ cross-reactivity with $\left[\mathrm{D}-\mathrm{Ala}{ }^{6}\right] \mathrm{GnRH}$, Des-Gly ${ }^{10}$-[D-Ala $]$ GnRH, [D-Phe ${ }^{2}$-D-Ala $\left.{ }^{6}\right] \mathrm{GnRH}$, [D-pGlu ${ }^{1}$-D-phe $\left.{ }^{2}-\mathrm{D}-\operatorname{Trp}^{3,6}\right] \mathrm{GnRH}$, somatostatin, serotonin, melatonin, substance $\mathrm{P}$, met- and leu-enkephalin, noradrenaline, L- and D-glutamic acid, PGE-2, GABA, dopamine, angiotensin I and II, TRH, LH, FSH, relaxin and oxytocin (data supplied by Dr Ramirez). However, antiserum CCR1IB73 does appear capable of binding to larger, prohormone GnRH molecules in the human brain (King et al., 1985). The final antiserum dilution was 1:50 000, in $0.02 \mathrm{M}$-phosphate buffered saline (PBS), pH 7.5, containing 0.1\% sodium azide, 0.05 $\mathrm{M}$-EDTA and 1:400 normal rabbit serum. At this antiserum dilution the $\% \mathrm{~B}_{\mathrm{o}}$ was $36 \%$ and the non-specific binding was $3-5 \%$. Synthetic GnRH (Peninsula Laboratories Inc., Belmont, CA 94002, U.S.A.) was used as the assay standard and iodinated according to Nett \& Adams (1977). Standards (0-200 pg/tube) and lyophilized samples were diluted in 0.02 M-PBS, pH 7.5, containing $0 \cdot 1 \%$ gelatin, $1 \mathrm{~mm}$-bacitracin and $0.1 \%$ sodium azide.

After addition of antiserum, tubes were incubated for $20 \mathrm{~h}$ at $4{ }^{\circ} \mathrm{C} .{ }^{125} \mathrm{I}$-labelled $\mathrm{GnRH}$ was added and after a further $24 \mathrm{~h}$ at $4^{\circ} \mathrm{C}$ the incubation was stopped by addition of polyethylene glycol 8000 (Union Carbide Corp., Danbury, CT 06917 , U.S.A.) in $0.02 \mathrm{M}-\mathrm{PBS}, \mathrm{pH} 7.5$, to a final concentration of $13.5 \%(\mathrm{w} / \mathrm{v})$, followed by $50 \mu \mathrm{l}$ ram serum. Tube contents were well mixed and centrifuged for $10 \mathrm{~min}$ at $2000 \mathrm{~g}$ and $10^{\circ} \mathrm{C}$. Bound counts were measured and $\mathrm{GnRH}$ concentrations determined using a Crystal 5400 Multidetector Gamma Counter System (United Technologies, Packard Instrument Co. Inc., Downers Grove, IL 60515, U.S.A.). The minimum detectable level of GnRH was $0.5 \mathrm{pg} / \mathrm{tube}$, equivalent to $0.1 \mathrm{pg} \mathrm{GnRH} / \mathrm{mg}$ tissue. The intra- and interassay coefficients of variation were $5 \cdot 4 \%$ and $12 \%$ respectively.

Statistical analysis. Data are expressed as the median and $95 \%$ confidence limits. Gene-specific differences were tested by Kruskal-Wallis analysis of variance. The Wilcoxon test for independent samples was used to test for significance between intact and ovariectomized groups.

\section{Results}

When serial dilutions of ME extracts from FF and ++ animals were assayed, the slopes of the dilution lines for FF and ++ ewes and the standard GnRH assay curve after logit-log transformation were $-0.531 \pm 0.105$ (s.d.; 6 dilutions; $r=0.91$ ), $-0.588 \pm 0.083$ (s.d.; 6 dilutions; $r=0.95$ ) 
Table 1. GnRH concentrations (pg/mg tissue) in the brains of intact and ovariectomized,$++ F+$ and FF Booroola ewes

\begin{tabular}{|c|c|c|c|c|c|c|}
\hline \multirow[b]{2}{*}{ Brain area } & \multicolumn{6}{|c|}{ Booroola genotype } \\
\hline & & ++ & & $\mathbf{F}+$ & & FF \\
\hline \multicolumn{7}{|l|}{ Intact sheep } \\
\hline Median eminence & 875 & $\begin{array}{l}(609-1374) \\
{[18]}\end{array}$ & 912 & $\begin{array}{l}(549-1950) \\
{[14]}\end{array}$ & 801 & $\begin{array}{l}(575-1315) \\
{[9]}\end{array}$ \\
\hline Medial basal hypothalamus & 38 & $\begin{array}{l}(25-93) \\
{[16]}\end{array}$ & 25 & $\begin{array}{l}(13-64) \\
{[17]}\end{array}$ & 32 & $\begin{array}{l}(22-46) \\
{[9]}\end{array}$ \\
\hline Preoptic area & 13 & $\begin{array}{l}(4 \cdot 0-25) \\
{[16]}\end{array}$ & $7 \cdot 2$ & $\begin{array}{l}(3 \cdot 4-15) \\
{[16]}\end{array}$ & & $\begin{array}{l}7(1 \cdot 7-8 \cdot 0) \\
{[9]}\end{array}$ \\
\hline OVLT/SON & $2 \cdot 5$ & $\begin{array}{l}(1 \cdot 5-21) \\
{[9]}\end{array}$ & $3 \cdot 5$ & $\begin{array}{l}(<0 \cdot 1-8 \cdot 1) \\
{[8]}\end{array}$ & & $\begin{array}{l}5(3 \cdot 6-19 \cdot 1) \\
{[5]}\end{array}$ \\
\hline Septal nuclei & $1 \cdot 4$ & $\begin{array}{l}(0.4-6.9) \\
{[6]}\end{array}$ & $2 \cdot 8$ & $\begin{array}{l}(<0 \cdot 1-4 \cdot 2) \\
{[9]}\end{array}$ & & $\begin{array}{l}7(<0 \cdot 1-5 \cdot 4) \\
{[7]}\end{array}$ \\
\hline Frontal cortex & $0 \cdot 2$ & $\begin{array}{l}(<0 \cdot 1-3 \cdot 8) \\
{[7]}\end{array}$ & $<0 \cdot 1$ & $\begin{array}{l}(<0 \cdot 1-0 \cdot 7) \\
{[8]}\end{array}$ & & $\begin{array}{l}5(<0 \cdot 1-1 \cdot 7) \\
{[5]}\end{array}$ \\
\hline Pineal & $0 \cdot 4$ & $\begin{array}{l}(<0 \cdot 1-0 \cdot 7) \\
{[5]}\end{array}$ & $0 \cdot 2$ & $\begin{array}{l}(<0 \cdot 1-2 \cdot 4) \\
{[5]}\end{array}$ & $<0 \cdot 1$ & $\begin{array}{l}1(<0 \cdot 1-0 \cdot 5) \\
{[5]}\end{array}$ \\
\hline Pituitary & 0.5 & $\begin{array}{l}(<0 \cdot 1-3 \cdot 8) \\
{[5]}\end{array}$ & $<0 \cdot 1$ & $\begin{array}{l}(<0 \cdot 1-6 \cdot 8) \\
{[5]}\end{array}$ & & $\begin{array}{l}8(<0 \cdot 1-2 \cdot 4) \\
{[5]}\end{array}$ \\
\hline $\begin{array}{l}\text { Ovariectomized sheep } \\
\text { Median eminence }\end{array}$ & 1752 & $\begin{array}{l}(879-2453)^{*} \\
{[12]}\end{array}$ & 1908 & $\begin{array}{l}(910-2902) \\
{[9]}\end{array}$ & 1398 & $\begin{array}{l}(820-2039)^{*} \\
{[11]}\end{array}$ \\
\hline Medial basal hypothalamus & 49 & $\begin{array}{l}(23-75) \\
{[14]}\end{array}$ & 40 & $\begin{array}{l}(23-62) \\
{[15]}\end{array}$ & 29 & $\begin{array}{l}(20-75) \\
{[13]}\end{array}$ \\
\hline Preoptic area & $0 \cdot 5$ & $\begin{array}{l}(0 \cdot 2-0 \cdot 8) \dagger \\
{[14]}\end{array}$ & $0 \cdot 7$ & $\begin{array}{l}(0 \cdot 4-0.9) \dagger \\
{[16]}\end{array}$ & & $\begin{array}{l}6(0 \cdot 2-1 \cdot 1) \dagger \\
{[12]}\end{array}$ \\
\hline
\end{tabular}

,$++ F+$ and FF are non-carriers, heterozygous carriers or homozygous carriers respectively of the Booroola $\mathrm{F}$ gene; OVLT $=$ organum vasculosum of the lamina terminalis; $\mathbf{S O N}=$ supraoptic nuclei.

Values are medians (with $95 \%$ confidence limits), for the no. of ewes per genotype indicated in square brackets.

Kruskal-Wallis analysis of variance revealed no significant $F$ gene-specific differences for intact or ovariectomized animals in the data from,$++ F+$ and $F F$ animals.

${ }^{*} P<0.05$ by the non-parametric Wilcoxon test when compared with intact animals of the same genotype.

$\dagger P<0.01$ by the Wilcoxon test when compared with intact animals of the same genotype.

and $-0.578 \pm 0.140$ (s.d.; 4 dilutions; $r=0.89$ ) respectively. Comparison of the slopes of the regression lines with one another revealed no significant differences. When aliqants of preoptic area extracts from ewes were added to $0,5,10,20$ and $50 \mathrm{pg}$ synthetic GnRH before RIA, the respective mean \pm s.e.m. $(n=8)$ values for ++ ewes were $8 \cdot 6 \pm 0 \cdot 08,12 \cdot 3 \pm 1 \cdot 3,18 \cdot 7 \pm 1 \cdot 4,28 \cdot 0 \pm 2 \cdot 2$ and $51.5 \pm 9.8 \mathrm{pg} /$ tube and for FF ewes $(n=8)$ they were $3.2 \pm 1 \cdot 0,8 \cdot 1 \pm 0.8,12.0 \pm 1 \cdot 0$, $22.9 \pm 1.7$ and $52.5 \pm 5.3 \mathrm{pg} /$ tube. These results indicate that the extracts contained insignificant GnRH-directed peptidase activity.

The concentrations of immunoactive GnRH measured in intact FF, F + and ++ Booroola ewes are shown in Table 1. High GnRH concentrations were found in the ME. Decreasing values were measured in $\mathrm{MBH}$, preoptic area, OVLT/SON and septal nuclei extracts respectively. The values obtained for the OVLT/SON showed large variations: $<0 \cdot 1-82 \mathrm{pg} / \mathrm{mg}$ tissue across all genotypes. This probably reflected a difficulty in identifying and dissecting out the OVLT, which is a small vascular body containing GnRH nerve terminals, situated in sheep on the dorsal edge of the optic chiasma next to the anterior lamina of the third ventricle (Lehman et al., 1986). Low or insignificant GnRH immunoactivity was found in extracts of cerebral cortex, pineal and pituitary 
gland. The distribution of GnRH immunoactivity obtained was similar to that obtained previously in sheep, using antisera capable of detecting prohormonal GnRH (Millar et al., 1977; Gale, 1986).

There were no significant differences in the values obtained for intact FF, F + and ++ animals in any of the brain regions tested.

The concentrations of immunoreactive GnRH in ovariectomized FF, F + and ++ Booroola ewes are summarized in Table 1. No gene-specific differences in GnRH concentrations were noted in any of the brain areas tested in the ovariectomized ewes. Ovariectomy increased the amount of GnRH in the ME, where the median concentrations were approximately twice those found in intact animals for all genotypes. However, this difference between intact and ovariectomized animals only reached significance (Wilcoxon test, $P<0.05$ ) in the $F F$ and ++ groups because of wide $95 \%$ confidence limits in the $\mathrm{F}+$ data. In the preoptic area there was a significant decrease in GnRH concentrations in ovariectomized ewes compared to those in intact animals in all genotypes (Wilcoxon test, $P<0 \cdot 01$ ). No significant changes were noted in the $\mathrm{MBH}$.

\section{Discussion}

Previous work on the Booroola ewe has shown increased gonadotrophin release and a decreased pituitary responsiveness to $\mathrm{GnRH}$ in vivo in FF compared with ++ animals (McNatty et al., 1987). These observations were compatible with increased GnRH release from the hypothalamus or changed pituitary receptor sensitivity in $\mathrm{FF}$ ewes. However, no significant $\mathrm{F}$ gene-specific differences were observed in the GnRH tissue concentrations of Booroola ewes. In a simplistic model increased GnRH release might be expected to result in lower hypothalamic peptide concentrations in animals with the $\mathrm{F}$ gene. However, no conclusions can be drawn about the dynamics of GnRH synthesis and release from data presented here on tissue immunoactivity. We conclude that the changed pituitary sensitivity and increased gonadotrophin release observed in $\mathrm{F}$ gene carriers is unlikely to be attributed to changed GnRH concentrations in the hypothalamus.

GnRH is synthesized in a prohormonal form in nerve cell bodies found throughout the preoptic area, OVLT and septal nuclei of the sheep (Lehman et al., 1986). This precursor protein is then processed by a series of specific enzymes to produce at least two bioactive peptides, GnRH and GnRH-associated peptide (Seeburg \& Adelman, 1984). These processing events occur within the neurosecretory granules as the newly synthesized hormone proceeds from the ribosomes in the perikarya to nerve terminals in the OVLT and ME (Lehman et al., 1986). Experiments using antisera directed to different parts of the GnRH decapeptide suggest that the prohormonal form is only detectable in the preoptic area and anterior hypothalamus, and that the majority of the GnRH immunoactivity measured in the ME is decapeptide (Millar et al., 1981; King et al., 1985; Gale, 1986). The GnRH antiserum used in this study has been shown to stain immunocytochemically the endoplasmic reticulum and neurosecretory granules in the perikarya of human anterior hypothalamus (King et al., 1985). The immunoactivity determined with this antiserum should therefore be a measure of the total prohormonal plus decapeptide $\mathrm{GnRH}$ concentration in the tissue. However, Antiserum CRR11B73 requires the complete decapeptide sequence for binding to occur, and so decapeptide degradation products are unlikely to contribute to the immunoactivity measured with this antiserum (King et al., 1985).

The distribution of GnRH in the hypothalamus changed in chronically ovariectomized animals, relative to that observed in intact ewes. In ovariectomized ewes the GnRH concentrations were about 2-fold higher in the ME and were reduced substantially in the preoptic area. A decrease in $\mathrm{MBH}$ and/or ME GnRH in response to long-term ovariectomy has been noted in the mouse (Briski et al., 1983), rat (Culler et al., 1982) and sheep (Wheaton, 1979). These results were initially interpreted as an increased release of the peptide under these conditions (Tytell et al., 1980; Millar et al., 1981; Shivers et al., 1983), but others have found an inhibition of GnRH release (Dluzen \& Ramirez, 1985, 1986) or a decrease in the amount of peptide available for release (Barnea $\&$ Cho, 
1985) after gonadectomy. Polkowska et al. (1980) noted that ovariectomy increased the numbers of GnRH-immunoreactive granules in the ME of the sheep. This observation and the results from the present study indicate an increase in GnRH synthesis, an inhibition of GnRH release, or a decrease in the degradation of the decapeptide in the ME nerve terminals of long-term ovariectomized sheep.

In contrast, the decreased GnRH immunoactivity measured by us in the preoptic area of the ovariectomized sheep would suggest a marked inhibition of GnRH biosynthesis in the absence of steroid hormones. Millar et al. (1981) have shown that the concentrations of both the precursor and decapeptide forms of GnRH decrease markedly in 2-week castrated male rats and that the levels of both forms rise when intact rats are implanted with oestradiol. Drouva et al. (1986), however, showed that levels of a $\mathrm{C}$ terminally-extended precursor form of $\mathrm{GnRH}$ increased in ovariectomized rats, concomitant with a decrease in the decapeptide. There is also some evidence that steroid hormones affect the activity of hypothalamic peptidases that degrade $\mathrm{GnRH}$, possibly influencing the amount of decapeptide stored in the ME (Griffiths et al., 1975; Advis et al., 1983). However, little is known about the effect of ovariectomy on the rate of prohormone processing events (Drouva et al., 1986), especially in the sheep. It is possible that the increase in GnRH in the ME noted after ovariectomy is partly caused by a drop in GnRH peptidase activity in the nerve terminals (Griffiths et al., 1975).

In conclusion these studies suggest that F-gene expression does not directly affect the tissue concentrations of GnRH in the hypothalamus of the Booroola ewe. However, altered GnRH release and turnover in F-gene carriers cannot be discounted.

We thank our colleagues at the Invermay Agricultural Research Centre, Mosgiel, New Zealand, for supplying the Booroola ewes, as well as providing the lifetime reproductive records of these animals. The GnRH antiserum was generously provided by Dr V. D. Ramirez, Department of Physiology and Biophysics, University of Illinois, Urbana, Illinois 61801, U.S.A.

\section{References}

Advis, J.P., Krause, J.E. \& McKelvy, J.F. (1983) Evidence that endopeptidase-catalyzed luteinizing hormone releasing hormone cleavage contributes to the regulation of median eminence LHRH levels during positive steroid feedback. Endocrinology 112, 1147-1149.

Barnea, A. \& Cho, G. (1985) Castration of male rats reduces the capacity of granules isolated from the median eminence to secrete luteinizing hormonereleasing hormone in response to copper. Neuroendocrinology 41, 149-155.

Bindon, B.M. (1984) Reproductive biology of the Booroola Merino sheep. Aust. J. biol. Sci. 37, 163-189.

Bindon, B.M., Piper, L.R., Cummins, L.J., O'Shea, J., Hillard, M.A., Findlay, J.K. \& Robertson, D.M. (1985) Reproductive endocrinology of prolific sheep: studies on the Booroola Merino. In Genetics of Reproduction in Sheep, pp. 217-235. Eds R. B. Land \& D. W. Robinson. Butterworths, London.

Briski, K.P., Baker, B.L. \& Christensen, A.K. (1983) Effect of ovariectomy on the hypothalamic content of immunoreactive gonadotrophin-releasing hormone in the female mouse as revealed by quantitative immunochemistry and radioimmunoassay. Am. J. Anat. 166, 187-208.

Culler, M.D., McArthur, H.N., Dees, W.L., Owens, R.E. \& Harms, P.G. (1982) Immunocytochemical evidence that suckling inhibits the post-ovariectomy depletion of median eminence luteinizing hormone releasing hormone. Neuroendocrinology 34, 258-264.

Davis, G. H., Montgomery, G.W., Allison, A.J., Kelly, R.W. \& Bray, A.R. (1982) Segregation of a major gene influencing fecundity in progeny of the Booroola sheep in New Zealand. N.Z. Jl agric. Res. 25, 525-529.

Dluzen, D.E. \& Ramirez, V.D. (1985) In-vivo activity of the LH-releasing hormone pulse generator in castrated and intact male rats. $J$. Endocr. 107, 331-340.

Dluzen, D.E. \& Ramirez, V.D. (1986) Transient changes in the in vitro activity of the luteinizing hormonereleasing hormone pulse generator after ovariectomy in rats. Endocrinology 118, 1110-1113.

Drouva, S.V., Gautron, J-P., Pattou, E., Laplante, E. \& Kordon, C. (1986) Effects of estradiol and progesterone on immunoreactive forms of hypothalamic luteinizing hormone-releasing hormone. Neuroendocrinology 43, 32-37.

Gale, J.S. (1986) Studies on the molecular mechanisms of the biosynthesis, metabolism and degradation of gonadotrophin releasing hormone in the sheep brain. Ph.D. thesis, University of Otago, New Zealand.

Griffiths, E.C., Hooper, K.C., Jeffcoate, S.L. \& Holland, D.T. (1975) The effects of gonadectomy and gonadal steroids on the activity of hypothalamic peptidases inactivating luteinizing hormone-releasing hormone (LH-RH). Brain Res. 88, 384-388.

King, J.C., Anthony, E.L.P., Fitzgerald, D.M. \& Stopa, E.G. (1985) Luteinizing hormone-releasing hormone 
neurons in human preoptic/hypothalamus: differential intraneuronal localization of immunoreactive forms. J. clin. Endocr. Metab. 60, 88-98.

Lehman, M.N., Robinson, J.E., Karsch, F.J. \& Silverman, A-J. (1986) Immunocytochemical localization of luteinizing hormone-releasing hormone (LHRH) pathways in the sheep brain during anestrus and the mid-luteal phase of the estrous cycle. J. comp. Neurol. 244, 19-35.

McNatty, K.P., Lun, S., Heath, D.A., Ball, K., Smith, P., Hudson, N.L., McDiarmid, J., Gibb, M. \& Henderson, K.M. (1986) Differences in ovarian activity between Booroola $\times$ Merino ewes which were homozygous, heterozygous and non-carriers of a major gene influencing their ovulation rate. J. Reprod. Fert. 77, 193-205.

McNatty, K.P., Hudson, N., Henderson, K.M., Gibb, M., Morrison, L., Ball, K. \& Smith, P. (1987) Differences in gonadotrophin concentrations and pituitary responsiveness to $\mathrm{GnRH}$ between Booroola ewes which were homozygous (FF), heterozygous $(\mathrm{F}+)$ and non-carriers $(++)$ of a major gene influencing their ovulation rate. J. Reprod. Fert. 80, 577-588.

Millar, R.P., Aehnelt, C. \& Rossier, G. (1977) High molecular weight immunoreactive species of luteinizing hormone releasing hormone: possible precursors of the hormone. Biochem. Biophys. Res. Commun. 74, 720-731.

Millar, R.P., Wegener, I. \& Schally, A.V. (1981) Putative prohormonal luteinizing hormone-releasing hormone. In Neuropeptides, pp. 11-130. Ed. R. P. Millar. Churchill Livingstone, Edinburgh.

Nett, T.M. \& Adams, T.E. (1977) Further studies on the radioimmunoassay of gonadotropin releasing hormone: effect of radioiodination, antiserum and unextracted serum on levels of immunoactivity in serum. Endocrinology 101, 1135-1144.

Palkovits, M. (1973) Isolated removal of hypothalamic or other brain nuclei of the rat. Brain Res. 59, 449-450.

Polkowska, J., Dubois, M-P. \& Domanski, E. (1980) Immunocytochemistry of luteinizing hormone releasing hormone (LHRH) in the sheep hypothalamus during various reproductive stages. Cell Tissue Res. 208, 327-341.

Robertson, D.M., Ellis, S., Foulds, L.M., Findlay, J.K. \& Bindon, B.M. (1984) Pituitary gonadotrophins in Booroola and control Merino sheep. J. Reprod. Fert. 71, 189-197.

Seeburg, P.H. \& Adelman, J.P. (1984) Characterization of cDNA for precursor of human luteinizing hormone releasing hormone. Nature, Lond. 311, 666-668.

Shivers, B.D., Harlan, R.E., Morrell, J.I. \& Pfaff, D.W. (1983) Immunocytochemical localization of luteinizing hormone-releasing hormone in male and female rat brains. Quantitative studies on the effects of gonadal steroids. Neuroendocrinology 36, 1-12.

Tytell, M., Clark, J.H. \& Peck, E.J., Jr (1980) Effects of estrogen and progesterone on LHRH release from a hypothalamic synaptosomal fraction of ovariectomized rats. Neurochem. Res. 5, 493-504.

Wheaton, J.E. (1979) Regional brain content of luteinizing hormone-releasing hormone in sheep during the estrous cycle, seasonal anestrus, and after ovariectomy. Endocrinology 104, 839-844.

Received 8 June 1987 